\title{
Enterprise Zones for Former Military Bases: Some Empirical Evidence from California's LAMBRA Program
}

\author{
Lee Hanson \\ Fred Hebein \\ California State University, San Bernardino
}

\begin{abstract}
LAMBRA is an enterprise zone program created by the state of California to encourage commercial reuse of deactivated military bases. This paper reports results of an exploratory study of LAMBRA's influence on business decisions to locate or expand at former installations. The study first interviewed local program managers in site visits, who reported that they had perceived limited economic impact of the LAMBRA program. Businesses at the LAMBRA locations then were surveyed. Statistical analysis of the surveys showed that few businesses at the sites had taken advantage of LAMBRA. The study presents recommendations for policy and future research.
\end{abstract}

\section{Introduction}

Beginning in the early 1980s, state governments throughout the United States established enterprise zones (EZs) offering business tax incentives to stimula te growth in distressed areas (Hirasuna and Michael, 2005). California inaugurated its EZ program in 1984, and by 2007 had authorized 42 enterprise zones in urban and rural areas around the state.

Within a few years of creating its enterprise zone program, California experienced a wave of military base closures stemming from post-Cold War defense cutbacks. By 1995, 29 installations had been deactivated or had pared operations, at a cost that state sources totaled at $\$ 9.6$ billion in revenues and 130,000 military and civilian jobs (California Trade and Commerce Agency, 1998). In response to this erosion of a pillar of the state economy, the legislature in 1993 enacted a new, targeted enterprise zone program to facilitate commercial reuse of former base properties. Unique among the states (although some ex-bases outside California have been designated enterprise zones), the program is called "Local Agency Military Base Recovery Area" or "LAMBRA." It offers most of the California EZ program incentives, with some salient differences. By 2001, eight LAMBRA designations had been authorized encompassing nine former installations. These included air force bases, naval and Marine Corps air stations, a naval training center, and a shipyard. Five of the sites are in northern, four in southern California.

To date the LAMBRA program has not been a subject of academic study. This paper presents results of a n examination of LAMBRA's economic impacts. Findings are reported from two research phases. First are results of in-person interviews with local program managers at the LAMBRA sites. Local economic development officials who oversee the program were asked about their perceptions of its impacts and 
management challenges. The second, more important set of results comes from a survey of businesses at LAMBRA sites. The questionnaire, which was developed from the literature review and site visit findings, was sent to all known businesses located at the seven LAMBRA sites with significant commercialization. Businesses were asked about industry and ownership characteristics, place of origin or from where they had relocated, staff levels and wage and hiring rates, and familiarity with LAMBRA and use of incentives. Survey data were analyzed using cross tabulations with Chi-square tests.

The paper begins with a survey of the academic research on enterprise zones. A tentative conclusion about LAMBRA is drawn from the review. Next, basic information is presented about LAMBRA incentives, the process for designating sites, and state tax evidence on utilization. This is followed by a description and summary of results of the site interviews. Next is described the questionnaire sent to businesses at the LAMBRA locations, followed by presentation of the findings of statistical analysis. Following a discussion of results, the paper concludes with implications for policy and research.

\section{Enterprise Zone Literature}

Since they were established in the early 1980s, enterprise zones have stimulated a growing body of research. The sophistication of studies has improved as initial case, survey, or shift-share methods have given way to multiple regression analyses, but findings about the economic impacts of enterprise zones remain inconclusive.

An early review of EZ studies from the 1980s compared the experience of the United States and the United Kingdom (Rubin and Richards, 1992). Central conclusions were that in order to successfully attract or incubate businesses, EZ's require a mix of viable industrial and commercial activities among distressed properties. Also important is active management of a zone program by a local professional staff, as distinct from passively offering incentives to businesses, a common occurrence. In a subsequent review, Wilder and Rubin (1996) concluded that the most consistent finding among empirical studies to that date was that while some increased job growth and investment occurred after enterprise zones were established, severely distressed areas required more assistance than EZ tax incentives alone provide.

More recent regression studies of EZ economic impacts have been summarized in a paper by Hirasuna and Michael (2005). They review articles by Greenbaum and Engberg (2004), O'Keefe (2004), Moore (2003), Peters and Fisher (2002), Beck (2001), and Bondonio and Engberg (2000), in addition to older studies by Sridhar (1999), Boarnet and Bogart (1996), and Papke (1991). They conclude that (p. 11):

Most studies suggest no significant and prolonged increases in employment from enterprise zones....Five studies find no increases in jobs, while three studies find at least a temporary increase in jobs and income. What causes the differences in results is uncertain. It might be related to statistical method, the data used for analysis, the particular program, or the economy within and surrounding the zone. 
Still-newer studies have added little clarity to these conclusions. Bostic and Prohofsky (2006) used individual tax returns for 1993 through 1997 to analyze wage and income growth for employee participants in two of California's enterprise zones, matching them with outside control groups. The results suggested that over the short-run, income increased more rapidly than for members of the control groups. Bondonio and Greenbaum (2007) used Census Bureau data between 1982 and 1992 from ten states and the District of Columbia to estimate impact of EZ incentives on employment, value of shipments, capital expenditures, and payroll per employee. They found that growth in new and existing establishments stimulated by zones was offset by losses among firms that closed or left, resulting in no net EZ impact.

Overall, the empirical research suggests that economic impacts of U.S. enterprise zones are generally modest where they do bring benefits. No existing studies would suggest that $E Z$ incentives, by themselves, have rejuvenated distressed areas. LAMBRA is a targeted form of enterprise zone. Assuming that the research on enterprise zones is applicable, the implication of the collective findings is that modest stimulus to base commercialization might realistically be expected from LAMBRA.

\section{California's LAMBRA Program}

LAMBRA legislation was modeled directly on California's enterprise zone law, and has incentives that are generally like those of enterprise zones. Exhibit 1 lists the incentives offered by the programs.

\section{EXHIBIT 1}

TAX INCENTIVES AVAILABLE UNDER LAMBRA AND ENTERPRISE ZONE PROGRAMS

Hiring tax credit - up to $\$ 31,605$ in state tax credits for each qualified disadvantaged employee hired.

Net Operating Loss Carryover - up to $100 \%$ of NOL may be carried forward for 15 years.

Unused tax credits can be applied to future tax years.

Sales and use tax credit for corporations on purchases of $\$ 20$ million per year of qualified manufacturing or processing machinery;

$\$ 1$ million annually for individuals.*

Upfront expensing of certain depreciable property, up to $\$ 40,000$ annually.

Preference points on state contracts.

Lenders credit - interest deduction for lending to zone businesses. ${ }^{*}$

${ }^{\star}$ Not available under LAMBRA 
There are two significant legislative and programmatic differences between the two programs. One is the duration of LAMBRA designations, which expire after eight years instead of the 15 years authorized for enterprise zones. According to state officials interviewed for this study, at the time the LAMBRA legislation was enacted it was expected that base conversion would proceed more readily than revitalization of distressed EZ communities. This belief was based in part on assumptions that bases were in good enough condition for ready commercialization. Subsequent experience proved this to be untrue. Extensions were authorized for some of the LAMBRA sites allowing them to "start the clock" some years after first being designated. In these cases, the life span of LAMBRA has been extended to be similar to enterprise zones.

A second difference between the two programs is a requirement for businesses claiming LAMBRA tax credits to generate a net increase in jobs in their first two years of participation. The job requirement is intended to help ensure that firms enjoying tax benefits create new employment in LAMBRA zones. The general absence of such mechanisms in enterprise zones has been a criticism (Wilder \& Rubin, 1996). Businesses state the number of jobs they expect to create within the first two years in their initial filing for tax credits. Subsequently, if they fail to meet target, any tax credits granted are reclaimed by the state's Franchise Tax Board. Firms are also barred from future participation in the program. In site visits, several local managers said that they believed the job-creation requirement had proven to be a disincentive for business participation.

To receive LAMBRA designation, the local government authority responsible for a deactivated base presented an application judged by state officials in a series of competitive "rounds" that began in 1993. The first three zones received conditional designation in 1996. By 2001, eight had been designated, encompassing nine former installations, two of them in the state capital at Sacramento. Closure of these nine installations had cost the state a total of 64,000 jobs (California Technology, Trade and Commerce Agency, 2002). By 2002, according to state data, approximately 325 businesses were operating at the nine LAMBRA locations, a figure that included some non-commercial organizations (e.g., schools, government units) not eligible for LAMBRA. A little over 6,000 workers were employed at the sites by that year, ten percent of the total military and civilian jobs lost with base closure.

State tax data on business utilization of LAMBRA incentives indicated low overall usage up to 2005, the last year reported in the most recent Franchise Tax Board memorandum on LAMBRA tax credits claimed (Franchise Tax Board, 2007). Between 1996, the first year incentives were available, and 2004, a total of $\$ 394,000$ in LAMBRA credits were claimed on 46 Personal Income Tax Returns (PIT). In addition to PITs are Bank and Corporation Tax Returns (BCT). In 1996, just three of these were filed, claiming $\$ 10,000$. By 2000 there were 16 BCT returns, totaling $\$ 312,000$, and in 2005 there were 20 , totaling $\$ 1,100,000$. Utilization of LAMBRA incentives clearly had increased, but the amounts involved remained comparatively small. In contrast, California enterprise zone incentives have been heavily utilized. According to the Franchise Tax Board, $\$ 770,207,000$ in tax credits was claimed in 2005 in 3,600 returns filed by 
businesses within the 37 existing enterprise zones. The tax evidence of low utilization is consistent with the conclusion drawn from the EZ literature that LAMBRA's economic impacts are likely to be modest.

\section{Interviews with Local LAMBRA Managers}

Field research for the study commenced with site visits to the LAMBRA locations and interviews with local economic development "zone managers" responsible for the program, conducted January - March 2006. Like local enterprise zone coordinators, LAMBRA zone managers are managers in a limited sense. Typically, their LAMBRA responsibilities are additions to other duties. Primarily, these consist of ensuring that their agency complies with LAMBRA program requirements, and reporting periodically to the state about program status. Zone managers have no official role in registering or authorizing firms to participate, and are not privy to firms' confidential tax data. They are expected to inform businesses which lease or buy base property about LAMBRA, provide them information about accounting and consulting firms that can assist, and encourage them to participate.

In the site interviews, zone mangers were asked their perceptions of LAMBRA economic impacts and about program management priorities and challenges. Summarizing these discussions, local managers had modest expectations for job growth during the lifetime of their LAMBRA zone. Virtually all claimed that their facilities were not ready for commercialization when turned over by the military and first required extensive upgrading. Partly as a result, LAMBRA status had had minimal or modest perceived economic impacts defined in terms of stimulating job-creation at a site, businesses opening a new facility separate from other locations, businesses relocating to a site, or economic activity in the immediate vicinity or surrounding community. Nonetheless managers still regarded LAMBRA as a valued part of their incentives for attracting businesses, along with mechanisms like redevelopment financing, bonding, and federal grants. Several claimed that LAMBRA status had been helpful in securing several projects that were expected to anchor and stimulate future development.

Zone managers felt that the main users of LAMBRA were larger corporate branch establishments. Small firms they saw as lacking the time or inclination to participate. The program was seen as most valuable for attracting employers opening new facilities, over either relocation or retention. Finally, managers nearly all felt that more aggressive marketing of LAMBRA at local and state levels was needed to attract businesses, though they also claimed that resources for marketing were limited. They reported that relatively little of their time was devoted to marketing or promoting the program.

Follow up email questions addressed the status of property within the LAMBRA zones. Zone managers were asked about current percentages of reused acreage, acreage transferred from Department of Defense to local authority, acreage yet requiring environmental cleanup in order to be redeveloped, and acreage that required new infrastructure prior to commencing commercial development. On average, something less than half of the base properties had been redeveloped, with considerable variation 
among sites. Extensive public investment infrastructure would be required to complete commercialization. Collectively, the responses indicated that transformation of the bases into viable commercial districts was expected to take $20-25$ years, with the start dates commencing in the mid-1990s when bases were closed. In effect, restoration to productive economic function was seen as a generation-long undertaking.

\section{Survey of Businesses at LAMBRA Sites}

The site interviews provided anecdotal insight about LAMBRA's perceived impacts on base commercialization from the perspective of local economic development officials. To obtain statistical evidence of LAMBRA's impacts upon location and growth decisions as reported by business owners or managers, a survey was created that drew from the EZ literature and the site visit findings.

The survey consisted of 16 questions in either Likert scale, forced-choice, or rank-order format. Businesses also were asked descriptive information (industry, ownership form, annual sales/revenues, etc.). The survey was sent to the firms located at the seven of the nine LAMBRA locations having significant business activity as of 2006. Mailing lists were provided by local zone managers. A total of 457 surveys were distributed, with 73 being returned, a response rate of 16 percent. The overwhelming majority of responding businesses were small ones with fewer than 100 full-time employees. Mean employment for the sample was 44.9 full-time workers (median 10.5). Full-time employment in the four largest firms was $996,331,225$, and 180 workers, respectively. None of these larger businesses was a unit of a national or multinational corporation.

\section{Statistical Analysis}

Statistical analysis of the survey data focused on the question of whether LAMBRA incentives had influenced firm location, expansion, or relocation and job creation, as well as level of awareness of LAMNRA. If the respondents reported that LAMBRA incentives were not influential, they were asked to explain why that was so.

\section{Location, Relocation, or Expansion}

The survey instrument provided six categories of business location. Based upon their answers, the respondents were divided into two groups. Group one is considered to be "local" business origin and is composed of the first two categories: (1) "We started the business here" and (2) "We relocated from another site within a hundred miles of here." Group two is considered to be "distant" business origin and consists of the next four categories which involved relocation or expansion from more distant areas: (3) "We relocated from another site over a hundred miles from here, but within California." (4) We relocated here from outside California." (5) "Our parent is a Califo rnia company that expanded by opening a new facility here." and (6) "Our parent is an out-of-state company that expanded by opening a new facility here". 
A fundamental issue to the importance of LAMBRA is whether its incentives influenced decisions about locating at LAMBRA sites. The survey question which evaluates LAMBRA influence is a Likert style question with five categories from "Not Very Important: to "Very Important". The null hypothesis tested is: "There is no difference in LAMBRA influence by category of location." The cross-tabulation of location category by LAMBRA influence with a Chi-square statistic is presented in Exhibit 2.

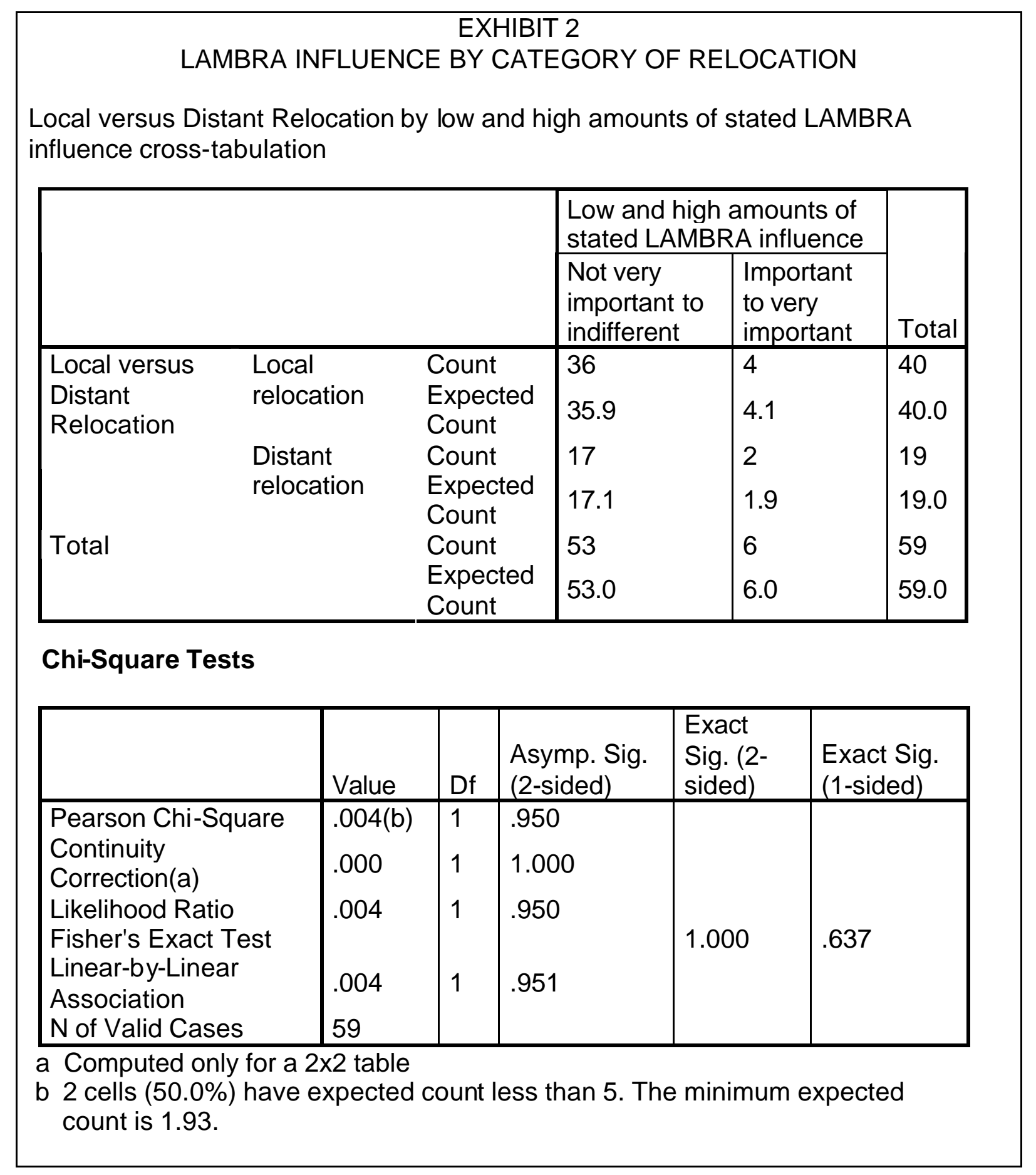


As Exhibit 2 shows, the null hypothesis cannot be rejected. That is, there is no influence by LAMBRA incentives on location category. The Pearson Chi-Square value is 0.004 with a statistically insignificant " $p$ " value of 0.950 . The respondents did not believe that LAMBRA incentives were important in their location choice.

\section{$\underline{\text { Job Creation and Number of Employees }}$}

While choice of location shows no influence by LAMBRA incentives, what about employment? Does LAMBRA influence job creation? Also, do LAMBRA incentives become more important if the company becomes larger in terms of number of employees? To address these questions we prepared two more cross-tabulations with chi-square statistics. The first cross tab tests the null hypothesis that "There is no difference in LAMBRA influence by the amount of job creation" (Exhibit 3). The second tests the null hypothesis that "There is no difference in LAMBRA influence by number of employees" (Exhibit 4).

As shown in Exhibit 3, the null hypothesis cannot be rejected. There is no LAMBRA influence by job creation. That is, companies that report larger amounts of jobs created do not indicate greater influence by LAMBRA incentives. The Pearson Chi-Square has a value of 0.095 with a statistically insignificant "p" value of 0.757 .

Similarly, as shown in Exhibit 4, the null hypothesis regarding number of employees cannot be rejected. That is, there is no LAMBRA influence by number of employees. The Pearson Chi-Square has a value of 0.741 with a statistically insignificant " $p$ " value of 0.389 .

\section{$\underline{\text { Sales }}$}

The statistical analysis to this point has shown that there is no influence by LAMBRA incentives by number of employees, number of jobs created, or by relocation. In this section, respondent companies are divided into two groups based upon sales revenue. Again, the null hypothesis for the cross tabulation has the form of "There is no difference in LAMBRA influence by company sales revenues." The cross tabulation and the statistical results are shown in Exhibit 5.

As can be seen, the null hypothesis regarding company sales revenues cannot be rejected. There is no LAMBRA influence by company sales revenues. The Pearson Chi-Square has a value of 0.351 with a statistically insignificant "p" value of 0.553 .

\section{Business Familiarity with LAMBRA}

A survey question (Q10) asked whether businesses were familiar with LAMBRA prior to locating at the site. Cross-tabulations were performed using this question with sales (Q9). The results of the cross tabs for sales are shown in Exhibit 6. 


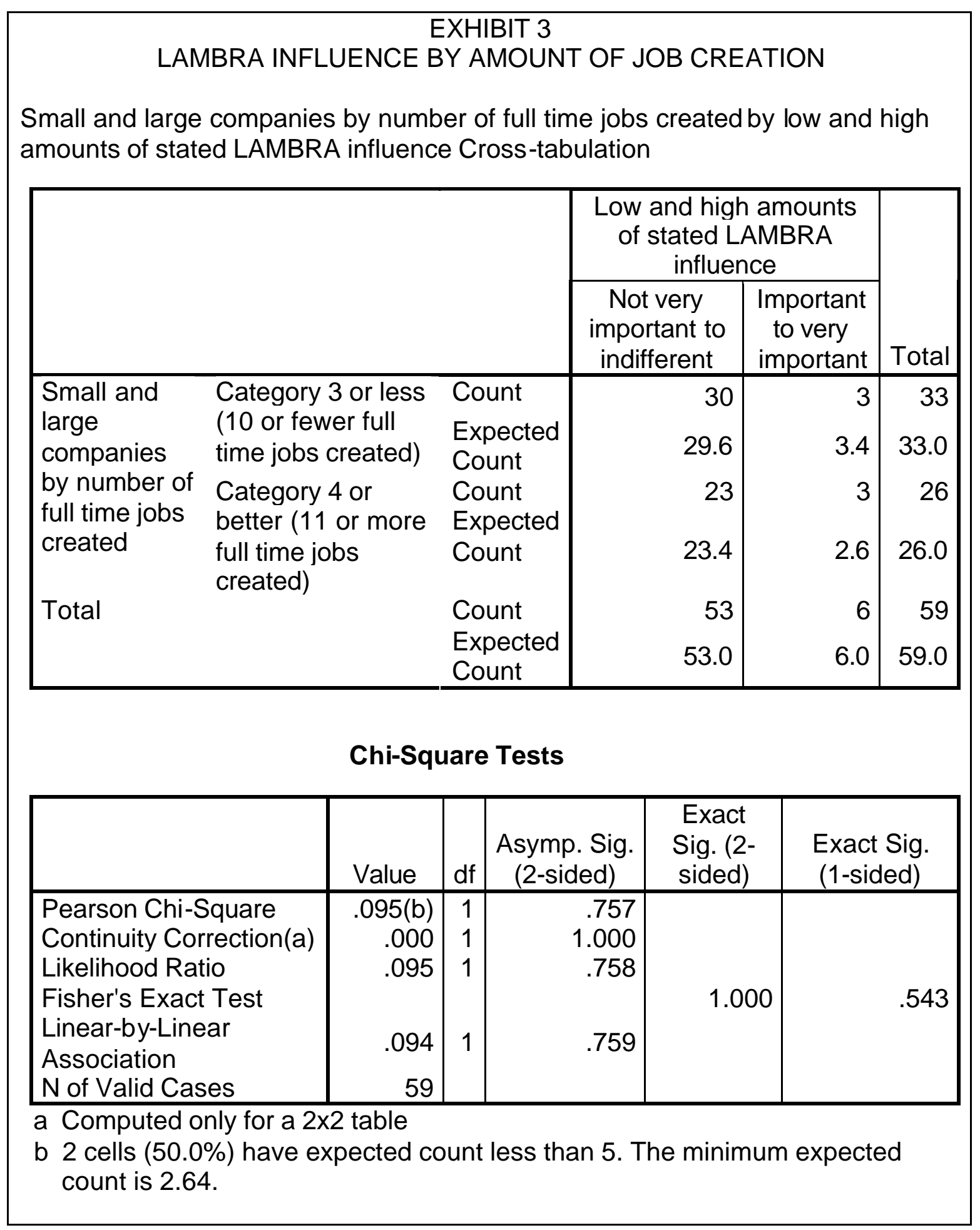




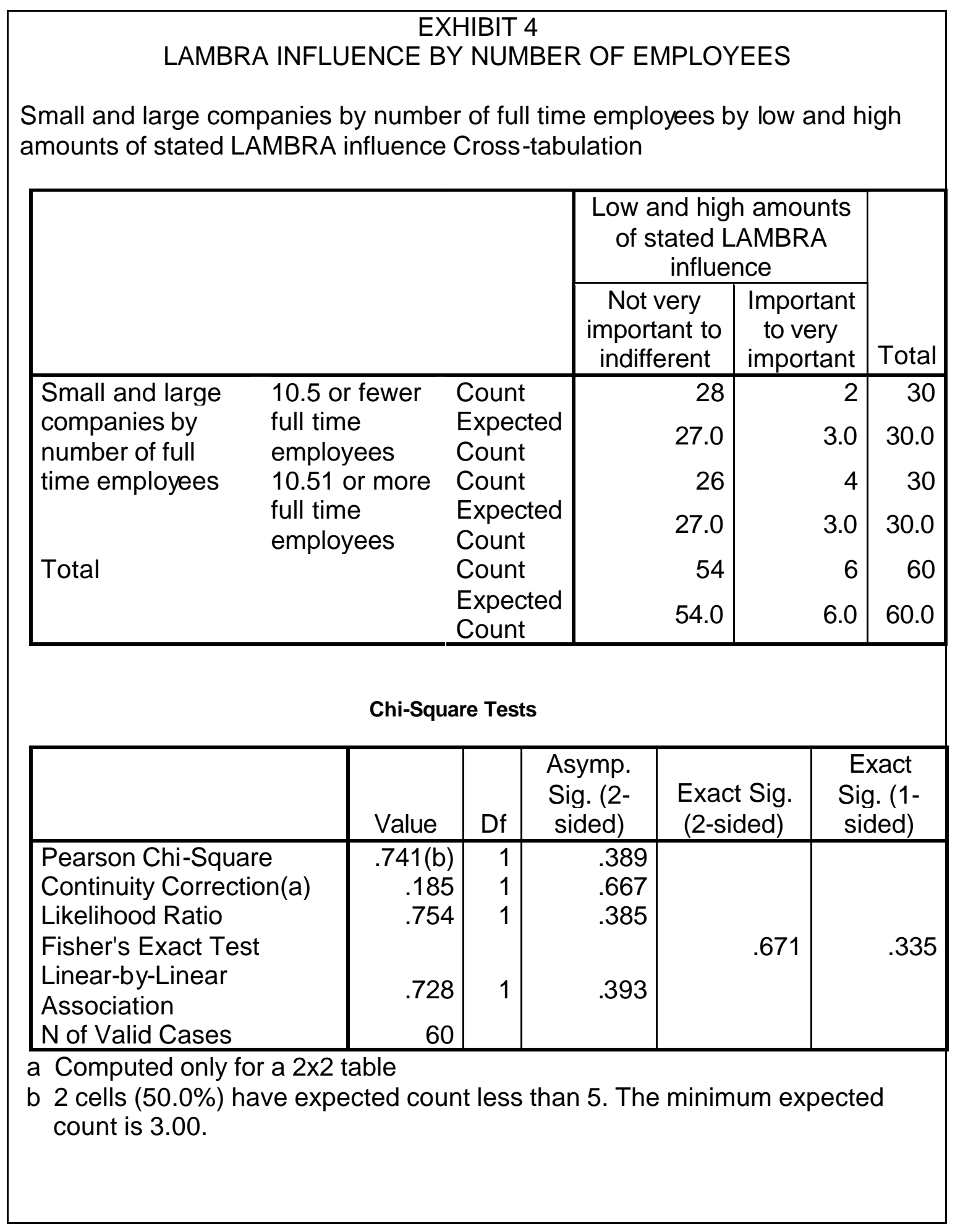




\section{LAMBRA INFLUENCE BY COMPANY SALES REVENUES}

Small and large companies by sales revenue (by) low and high amounts of stated LAMBRA influence Cross-tabulation

\begin{tabular}{|c|c|c|c|c|c|}
\hline & \multicolumn{2}{|c|}{$\begin{array}{l}\text { Low and high amounts of } \\
\text { stated LAMBRA influence }\end{array}$} & \multirow[b]{2}{*}{ Total } \\
\hline & & & $\begin{array}{c}\text { Not very } \\
\text { important to } \\
\text { indifferent }\end{array}$ & $\begin{array}{l}\text { Important to } \\
\text { very } \\
\text { important }\end{array}$ & \\
\hline \multirow{4}{*}{$\begin{array}{l}\text { Small and large } \\
\text { companies by } \\
\text { sales revenue }\end{array}$} & $\begin{array}{l}\text { Category } 4 \\
\text { or less }\end{array}$ & $\begin{array}{l}\text { Count } \\
\text { Expected }\end{array}$ & 37 & 3 & 40 \\
\hline & & Count & 36.4 & 3.6 & 40.0 \\
\hline & Category 5 & $\begin{array}{l}\text { Count } \\
\text { Expected }\end{array}$ & 14 & 2 & 16 \\
\hline & $\begin{array}{l}(\$ 5,000,000 \\
\text { or more) }\end{array}$ & Count & 14.6 & 1.4 & 16.0 \\
\hline \multirow[t]{2}{*}{ Total } & & Count & 51 & 5 & 56 \\
\hline & & $\begin{array}{l}\text { Expected } \\
\text { Count }\end{array}$ & 51.0 & 5.0 & 56.0 \\
\hline
\end{tabular}

\section{Chi-Square Tests}

\begin{tabular}{|c|c|c|c|c|c|}
\hline & Value & $d f$ & $\begin{array}{l}\text { Asymp. } \\
\text { Sig. (2- } \\
\text { sided) }\end{array}$ & $\begin{array}{l}\text { Exact } \\
\text { Sig. (2- } \\
\text { sided) }\end{array}$ & $\begin{array}{l}\text { Exact } \\
\text { Sig. (1- } \\
\text { sided) }\end{array}$ \\
\hline Pearson Chi-Square & $.351(\mathrm{~b})$ & 1 & .553 & \multirow{6}{*}{617} & \multirow{6}{*}{.445} \\
\hline Continuity Correction(a) & .005 & 1 & .941 & & \\
\hline Likelihood Ratio & .331 & 1 & .565 & & \\
\hline Fisher's Exact Test & & \multirow{3}{*}{1} & \multirow{3}{*}{.557} & & \\
\hline Linear-by-Linear & .345 & & & & \\
\hline $\mathrm{N}$ of Valid Cases & 56 & & & & \\
\hline
\end{tabular}

a Computed only for a $2 \times 2$ table

b 2 cells $(50.0 \%)$ have expected count less than 5 . The minimum expected count is 1.43 . 


\section{EXHIBIT 6}

FAMILIARITY WITH LAMBRA BY COMPANY SALES REVENUES

Small and large companies by sales revenue (by) low and high amounts of stated LAMBRA influence Cross-tabulation

\begin{tabular}{|c|c|c|c|c|c|}
\hline & \multicolumn{2}{|c|}{$\begin{array}{l}\text { Low and high amounts of } \\
\text { stated LAMBRA influence }\end{array}$} & \multirow[b]{2}{*}{ Total } \\
\hline & & & Yes & No & \\
\hline \multirow[t]{2}{*}{$\begin{array}{l}\text { Small and large } \\
\text { companies by } \\
\text { sales revenue }\end{array}$} & $\begin{array}{l}\text { Category } 4 \\
\text { or less } \\
\text { ( } \$ 4.999,999 \\
\text { or smaller) }\end{array}$ & $\begin{array}{l}\text { Count } \\
\text { Expected } \\
\text { Count }\end{array}$ & $\begin{array}{c}2 \\
5.5\end{array}$ & $\begin{array}{r}43 \\
39.5\end{array}$ & $\begin{array}{l}45 \\
45\end{array}$ \\
\hline & $\begin{array}{l}\text { Category } 5 \\
\text { or larger } \\
(\$ 5,000,000 \\
\text { or more })\end{array}$ & $\begin{array}{l}\text { Count } \\
\text { Expected } \\
\text { Count }\end{array}$ & $\begin{array}{c}6 \\
2.5\end{array}$ & $\begin{array}{c}14 \\
17.5\end{array}$ & $\begin{array}{l}20 \\
20\end{array}$ \\
\hline Total & & $\begin{array}{l}\text { Count } \\
\text { Expected } \\
\text { Count }\end{array}$ & 8 & 57 & $\begin{array}{l}65 \\
65\end{array}$ \\
\hline
\end{tabular}

Chi-Square Tests

\begin{tabular}{|l|c|r|c|c|c|}
\hline & Value & df & $\begin{array}{c}\text { Asymp. } \\
\text { Sig. (2- } \\
\text { sided) }\end{array}$ & $\begin{array}{c}\text { Exact } \\
\text { Sig. (2- } \\
\text { sided) }\end{array}$ & $\begin{array}{c}\text { Exact } \\
\text { Sig. (1- } \\
\text { sided) }\end{array}$ \\
\hline Pearson Chi-Square & $8.378(\mathrm{~b})$ & 1 & .004 & & \\
Continuity Correction(a) & 6.178 & 1 & .013 & & \\
Likelihood Ratio & 7.693 & 1 & .006 & .008 & .008 \\
Fisher's Exact Test & & & & & \\
Linear-by-Linear & 8.250 & 1 & .004 & & \\
Association & 65 & & & & \\
N of Valid Cases & & & & & \\
\hline
\end{tabular}

a Computed only for a $2 \times 2$ table

b 1 cell $(25.0 \%)$ have expected count less than 5 . The minimum expected count is 2.46 . 
The null hypothesis, which was that there was no difference in familiarity with LAMBRA by company size (defined by sales), was rejected, showing that while smaller firms were not familiar with LAMBRA, larger firms were. The Chi-Square test was statistically significant.

Overall, and consistent with the conclusions derived from the EZ literature review, evidence of state tax data, and site interviews with zone mangers, the statistical analysis of business survey results indicated limited economic impact of LAMBRA incentives on base commercialization. Larger firms were more likely to be familiar with LAMBRA, but evidently not greatly more inclined to take advantage of it.

\section{Discussion and Implications}

At the broadest level, the results of the study corroborate research findings that enterprise zones in the United States have generally had limited impact in revitalizing distressed areas. The survey of businesses at the LAMBRA sites suggests that the program has had little influence on location decisions or growth of businesses operating there. The statistical analysis of the survey results revealed little familiarity with LAMBRA among the majority small firms, corresponding low utilization of its tax incentives, and no significant impact of incentives on location decisions, job-creation, or sales-generation, even by larger firms that were more familiar. Assuming that these results are representative of most of the 400 -plus companies currently populating the former military bases, businesses that have chosen to locate there have done so not because of state government incentives, but out of traditional motivations like cost and availability of land, availability of labor force or infrastructure, transportation access, or other firm-specific reasons.

Several reasons may explain why LAMBRA has not been used more heavily. One is the continuing problems of acreage that remains undevelopable because of ownership, environmental, or infrastructure problems. Like distressed enterprise zone communities, these drawbacks may easily offset the attractiveness of tax incentives meant to draw businesses. In particular, they could be leading large firms of the type most disposed to utilize economic development incentives to rule out LAMBRA sites for consideration. Another reason for non-use is likely to be the limited promotion of the LAMBRA program to which zone managers readily attested, mainly, they claimed, because of lack of resources to devote to that task. The frank admission of the essentially passive management of the program is interesting in light of enterprise zone literature that has been skeptical of the reliability of official reports of enterprise zone program impacts (Wilder \& Rubin, 1996). In this case, while zone managers valued LAMBRA as an economic development tool, they did not try to conceal the reality either of limited program promotion or of perceived impacts.

A third possible reason for lack of utilization is the requirement in the legislation of jobcreation, which state and local program officials alike felt is a disincentive. The jobs requirement would seem especially likely to worry small firms with uncertain growth potential, which are also likely to have limited time and resources to engage in the tax- 
filing process. A fourth, related reason is the reality that small businesses that have little prospect of adding employees or making significant capital investments generally can derive little advantage from LAMBRA's (or EZ) hiring or investment tax credits. In practice, it is growth businesses - firms that can add staff or production capacity - that can benefit from incentives like those of LAMBRA or enterprise zones. However, at the LAMBRA sites, for whatever their reasons most small growth firms also have been disinclined to participate in the program. Given the similarity of LAMBRA and EZ incentives and the vigorous utilization of enterprise zone incentives documented by state tax data, it seems unlikely that LAMBRA's tax benefits are not seen as valuable or that complexity of the tax filing process per se would turn businesses away, despite some evidence to that effect in the survey results. In the absence of other explanations, LAMBRA's job creation requirement, combined with limited promotion and program familiarity, would seem more likely causes.

These conclusions raise some implications for policy. First, in order for state and local officials to increase utilization of LAMBRA, more investment is needed not simply in promoting the program, but in selectively providing businesses help or guidance in executing the relevant paperwork. To be cost-effective, however, technical assistance mainly should be targeted to small firms that are growing or have potential for growth, as distinct from all small firms at a site. There is little point in investing time and energy in trying to engage small businesses that have little or no potential for growth. Large firms interested in LAMBRA may also be assisted, but in practice they will warrant less of it because of their greater resources and capacity to meet tax reporting requirements.

A related policy recommendation concerns LAMBRA's requirement for businesses to meet self-defined job-creation targets, which does not apply to enterprise zones. While its aim is to help ensure that participating LAMBRA businesses create new employment, there is some reason to believe that it acts to inhibit participation. An assessment by state officials would be desirable to determine whether the job-creation requirement is impeding participation, and if it is, whether modification (if not outright elimination) would better serve LAMBRA's purpose of promoting commercial reuse of former bases.

The study also has implications for future research. All of the LAMBRA locations have drawn at least a few substantial corporate branch establishments, but none of these responded to the survey. Consequently this study effectively examined only one segment of the population of LAMBRA firms, the small, local ones. The motivations and actions of the other, large-firm segment have largely remained outside the analysis. This could be a serious omission given that larger firms have the resources to take advantage of state and local economic development incentive programs, and by reputation at least are disposed to do so as fully as possible (LeRoy, 2005). While there is little evidence in state tax data to suggest that larger firms are using LAMBRA on a significant scale, a second survey that focused solely upon the large firms at LAMBRA sites could help illuminate why they have not done so. A survey could also shed light on whether the mere existence of an incentive zone serves to draw larger firms by signaling a "friendly business climate" (Wilder \& Rubin, 1996), regardless of whether incentives ultimately are used. Such information could help policy makers determine 
the extent to which the LAMBRA program is or is not an effective policy tool for stimulating base commercialization by the kinds of large firms possessing the financial means to make significant investments in upgrading base properties.

Another research effort that might help in gauging the requirements for effective LAMBRA or enterprise zone programs would be to examine the differences between U.S. enterprise zones and China's Special Economic Zones (SEZs), which have been credited with sparking China's emergence as a world manufacturing center (Zheng, 2006). Western enterprise zones were inspired by study of the low-tax and -regulation "freeports" of Hong Kong, Singapore and Taiwan (Hirasuna \& Michael, 2005). However, the EZ literature has not made any systematic comparisons between them. It is possible that China's SEZ's are too different from western incentive zones to allow for meaningful comparison. In China the state plays a significant role in operating the zones, which are attractive to foreign direct investment seeking low-cost manufacturing, while there also are fundamental differences in economic contexts, with China industrializing rapidly, while enterprise zone communities in the United States typically are distressed because of long-term de-industrialization. Still, with enterprise zone policy nearly thirty years old but its efficacy in dispute, it would be useful to understand better why this should be so. Comparative analysis of the management practices, land use policies, and type and value of incentives offered in China's Special Economic Zones might yield valuable lessons about the kind of commitments state governments in the United States would need for their enterprise zones to really succeed.

\section{REFERENCES}

Beck, F.D. (2001). Do state-designed enterprise zones promote economic growth? Sociological Inquiry 61(4), 508-32.

Boarnet, M.G., \& Bogart, William T (1996). Enterprise zones and employment: Evidence from New Jersey. Journal of Urban Economics, 40, 198 - 215.

Bondonio, D., \& Engberg, J. (2000). Enterprise zones and local employment: Evidence from the States' Programs. Regional Science and Urban Economics, $30,519-549$.

Bondonio, D. \& Greenbaum, R. (2007). Do local tax incentives affect economic growth? What mean impacts miss in the analysis of enterprise zone policies. Regional Science and Urban Economics, 37, 121 - 136.

Bostic, R.W., \& Prohosky, A.C. (2006). Enterprise zones and individual welfare: A case study of California. Journal of Regional Science 46(2), 175-203.

California Franchise Tax Board, Statistics Relating to Various Tax Incentive Zones, 2005 Tax Year (August 9, 2007). 
California Trade and Commerce Agency (1998). Local Agency Military Base Recovery Area (LAMBRA) 1997-98 Report to the Legislature. Sacramento.

California Technology, Trade and Commerce Agency (2002). LAMBRA Annual Report to the Legislature. Sacramento.

Couch, J.F., Atkinson, K.E., \& Smith, L.H. (2005). The impact of enterprise zones on job creation in Mississippi. Contemporary Economic Policy, 23(2), 255- 260.

Greenbaum, R.T., \& Engberg, J.B. (2004). The impact of state enterprise zones on urban manufacturing establishments. Journal of Policy Analysis and Management, 23(2), 315 - 339 .

Hirasuna, D. \& Michael, J. (2005). Enterprise zones: a review of the economic theory and empirical evidence. Policy Brief, Minnesota House of Representatives.

Leroy, G (2005). The great american jobs scam: corporate tax dodging and the myth of job creation. San Francisco: Berrett-Koehler Publishers.

Moore, W.S. (2004). Enterprise zones, firm attraction and retention: A study of the California enterprise zone program. Public Finance and Management, 3(3), 376-92.

O'Keefe, S. (2004). Job creation in California's enterprise zones: A comparison using a propensity score matching model. Journal of Urban Economics, 55(1), 131 50.

Papke, L.E. (1991). Tax policy and urban development: evidence from an enterprise zone program. Working paper 3945, National Bureau of Economic Research.

Peters, A.H., \& Fisher, P.S. (2002). State enterprise zone programs: Have they worked? Kalamazoo, MI: W.E. Upjohn Institute for Employment Research.

Rubin, B. M., \& Richards, C. M. (1992, November). A transatlantic comparison of enterprise zone impacts: The British and American experience. Economic Development Quarterly, 6, 431 - 443.

Sridhar, K.S. (1999). Tax incentive programs and unemployment rate. Review of Regional Studies, 30(3), 375-98.

Wilder, M.G., \& Rubin, Rubin, B. M. (1996, Autumn). Rhetoric versus reality: A review of studies on state enterprise zone programs. Journal of the American Planning Association, 62(4), $473-491$. 
Zheng, Y. (2006, March) Institutions matter: how do special economic zones attract Foreign direct investment in China? Paper presented at the annual meeting of the International Studies Association, Town \& Country Resort and Convention Center, San Diego, California. 